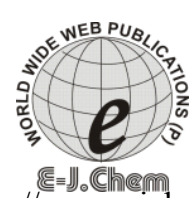

\title{
ICP-OES Determination of Trace Metal Ions after Preconcentration Using Silica Gel Modified with 1,2-Dihydroxyanthraquinone
}

\author{
REEM M. ALGHANMI ${ }^{*}$ \\ Department of Chemistry, Sciences Faculty for Girls \\ King Abdulaziz University, Jeddah, Saudi Arabia \\ omareej_ygh@hotmail.com
}

Received 20 September 2011; Accepted 9 November 2011

\begin{abstract}
A new chelating matrix was prepared by immobilizing 1,2-dihydroxyanthraquinone, or alizarin (AZ), on silica gel modified with (3aminopropyl)trimethoxysilane. The matrix was characterized by FTIR spectroscopy and elemental analysis. The new matrix was used to preconcentrate $\mathrm{Cd}(\mathrm{II}), \mathrm{Cu}(\mathrm{II}), \mathrm{Ni}(\mathrm{II}), \mathrm{Pb}$ (II) and $\mathrm{Zn}$ (II) prior to their determination by inductively coupled plasma optical emission spectrometry (ICP-OES). The optimum $\mathrm{pH}$ was 5 and the optimum extraction time was approximately 15 minutes using the batch method. Common electrolytes and metal ions did not interfere with the separation and determination of the analytes. The adsorption capacity of the new sorbent was $67.4,163.5,212.8,76.4$ and $180.3 \mu \mathrm{mol} / \mathrm{g}$ for $\mathrm{Cd}(\mathrm{II}), \mathrm{Cu}(\mathrm{II})$, $\mathrm{Ni}(\mathrm{II}), \mathrm{Pb}(\mathrm{II})$ and $\mathrm{Zn}(\mathrm{II})$, respectively. The relative standard deviations (RSD) were less than $3.0 \%$. This method allowed for successful separation and preconcentration of trace metal ions in different water samples with satisfactory results.
\end{abstract}

Keywords: Silica gel, 1,2-Dihydroxyanthraquinone, Immobilization, Solid-phase synthesis.

\section{Introduction}

Over the last two decades, metal ions have been the focus of numerous studies of contaminants present in aquatic environments. Their increasing presence in aquatic compartments and organisms raises major public health concerns ${ }^{1-3}$. Numerous harmful health effects, such as high blood pressure and kidney and nervous system impairment, have been linked to exposure to metal ions such as cadmium and lead. All these metals, including copper, are considered toxic to aquatic biota ${ }^{3}$ Separation and preconcentration of the metallic ion analytes is necessary for further studied, particularly when they occur at trace levels.

There are many traditional separation and preconcentration methods that can be used between the sample collection and analysis by atomic absorption spectrometry (AAS) or inductively coupled plasma optical emission (ICP-OES). These methods, including liquid- 
liquid extraction, coprecipitation, and ion exchange, often require large amounts of highpurity organic solvents, some of which are harmful and cause environmental problems. Currently, the solid-phase extraction (SPE) method is one of the most effective multielemental preconcentration methods and has many advantages, such as ease of use, high preconcentration factor, rapid phase separation, low cost, low consumption of organic solvents, and the detection in on-line or off-line modes $^{4-5}$.

Of the many types of solid phase used in SPE, silica gel immobilized by various organic compounds that use a metal chelating agent to remove, extract, separate and preconcentrate metal ions from different matrices display high thermal, chemical and mechanical stability ${ }^{6}$ and is less susceptible to swelling, shrinking, and microbial and radiation decay ${ }^{7-10}$.

The selectivity of the modified silica gel mainly depends on the structure of the immobilized organic compound as a whole, the nature of the incorporated donor atoms $(\mathrm{O}$, $\mathrm{N}, \mathrm{P}$ and $\mathrm{S}$ ), the positioning of the functional groups along the surface of the silica, and the steric requirements of the complex formed after uptake of the desired metal ion ${ }^{11-13}$.

A variety of chelating ligands have been used to modify a silica gel surface. Modification of the surface is done using an appropriate molecule designated as the precursor silylating agent. The covalent bond formed between the silica surface and the silylating agent yield a new modified silica surface with anchored functionality. It is then possible to immobilize new molecules with a variety of organic functions, including chelating agents ${ }^{7,14-20}$.

Silica gel functionalized with 1,8-dihydroxyanthraquinone ${ }^{21}, 2$-aminomethylpyridine ${ }^{22}$, $p$-dimethylaminobenzaldehyde, ${ }^{23}$ 4-(8-hydroxy-5-quinolyazo) naphthalene, ${ }^{24}$ 2,4,6-trimorpholine-1,3,5-triazin ${ }^{25}$, benzophenone 4- aminobenzoyl-hydrazine ${ }^{19}$, 4-amino-2-mercaptopyrimidine $^{13}$, ethyl-2-benzothi-azolylacetate ${ }^{26}$ have been used to enrich for metal ions, $\mathrm{Cd}(\mathrm{II}), \mathrm{Co}(\mathrm{II}), \mathrm{Cu}(\mathrm{II}), \mathrm{Ni}(\mathrm{II}), \mathrm{Pb}(\mathrm{II})$ and $\mathrm{Zn}(\mathrm{II})$. The modified silica have been used in various areas, most notably in metal ion preconcentration ${ }^{27}$, ion exchange, ${ }^{28,29}$ biotechnology ${ }^{30}$, sensors ${ }^{31}$, catalysis $^{32-34}$, pesticides removal ${ }^{35}$ and green chemistry ${ }^{36}$.

In this study, 1,2-dihydroxyanthraquinone (alizarin, AZ) was immobilized on the surface of a silica gel to create a new solid-phase extractant. The new phase has been characterized by FTIR spectroscopy and elemental analysis. The new sorbent (SG-AZ) was successfully applied to the preconcentration and determination of $\mathrm{Cd}(\mathrm{II}), \mathrm{Cu}$ (II) $\mathrm{Ni}(\mathrm{II})$, $\mathrm{Pb}(\mathrm{II})$ and $\mathrm{Zn}(\mathrm{II})$ in aqueous solutions and environmental samples.

\section{Experimental}

The silica gel (60-120 mesh size) and (3-aminopropy)trimethoxysilane used in this study were purchased from Fluca Chemie, AG, Switzerland. Alizarin was purchased from BDH Chemicals Company, (Poole, England) and used as received. Organic solvents were purified and dried according to conventional methods. Stock solutions of metal ions $(1 \mathrm{mg} / \mathrm{mL})$ were prepared from analytical reagent grade nitrate salts by dissolving the appropriate amount in $1.0 \% \mathrm{HNO}_{3}$ and were diluted daily prior to use with doubly distilled water (DDW). $\mathrm{pH}$ adjustments were made with $0.2 \mathrm{~mol} / \mathrm{L} \mathrm{KCl}-\mathrm{HCl}$ buffer ( $\mathrm{pH} 1-2), 0.1 \mathrm{~mol} / \mathrm{L}$ acetate-acetic acid buffer $(\mathrm{pH} \mathrm{3-6)}$ and $0.1 \mathrm{~mol} / \mathrm{L}$ phosphate buffer ( $\mathrm{pH} 7-8)$.

\section{Apparatus}

\section{Inductively coupled plasma optical emission spectrometry (ICP-OES)}

Metal ions were determined using a Perkin Elmer Optima 4100 DV with a cross-flow nebulizer and a Ryton Scott chamber. 


\section{Elemental analysis}

Elemental analysis was performed with a Perkin Elmer 2400 elemental analyzer.

\section{Infrared spectra (FTIR)}

Infrared spectra were measured as $\mathrm{KBr}$ discs on a ShimadzuFTIR-8400 Fourier transform infrared spectrophotometer (Japan), evacuated to avoid water and $\mathrm{CO}_{2}$ absorption. Each spectrum consisted of 64 scans.

\section{Adjustment of $\mathrm{pH}$}

The $\mathrm{pH}$ value was adjusted using a Hanna $\mathrm{pH} 212$ digital $\mathrm{pH}$ meter with a glass-body double junction electrode calibrated using standard buffer solutions at $25 \pm 0.1^{\circ} \mathrm{C}$.

\section{Synthesis of Modified Silica Gel Phase}

\section{Activation of silica gel phase (SG)}

In order to remove any adsorbed metal ions and increase the content of $-\mathrm{OH}, 50.0 \mathrm{~g}$ of silica gel was activated by refluxing for $8 \mathrm{~h}$ with $6 \mathrm{~mol} / \mathrm{L}$ hydrochloric acid. The silica gel was filtered, washed with DDW until it was free of acid and dried in an oven at $160{ }^{\circ} \mathrm{C}$ for $8 \mathrm{~h}$.

\section{Synthesis of silica gel modified with 3-aminopropyl-trimethoxysilane (APSG)}

First, $14.0 \mathrm{~g}$ of activated silica gel was dispersed into $150 \mathrm{~mL}$ of dry toluene in a flask and then $14.0 \mathrm{~mL}$ of 3 -aminopropyl-trimethoxysilane was added to the solution. The reaction mixture was stirred and refluxed for $8 \mathrm{~h}$, left to cool, filtered, washed with toluene, ethanol, and diethyl ether, and finally dried at $70{ }^{\circ} \mathrm{C}$.

\section{Synthesis of the $S G-A Z$ sorbent}

Alizarin $(2.4 \mathrm{~g})$ was dissolved in $150 \mathrm{~mL}$ dry toluene with $10 \mathrm{~mL}$ dimethylsulfoxide (DMSO) and then $6.0 \mathrm{~g}$ of APSG was added. The reaction mixture was refluxed overnight with continues stirring, left to cool, filtered, washed with toluene, ethanol and dried at $70{ }^{\circ} \mathrm{C}$ for $7 \mathrm{~h}$. During this reaction, the weight of the product increased, indicating that the new sorbent was successfully modified with alizarin. The synthesis route of SG-AZ is schematically represented in Scheme 1.

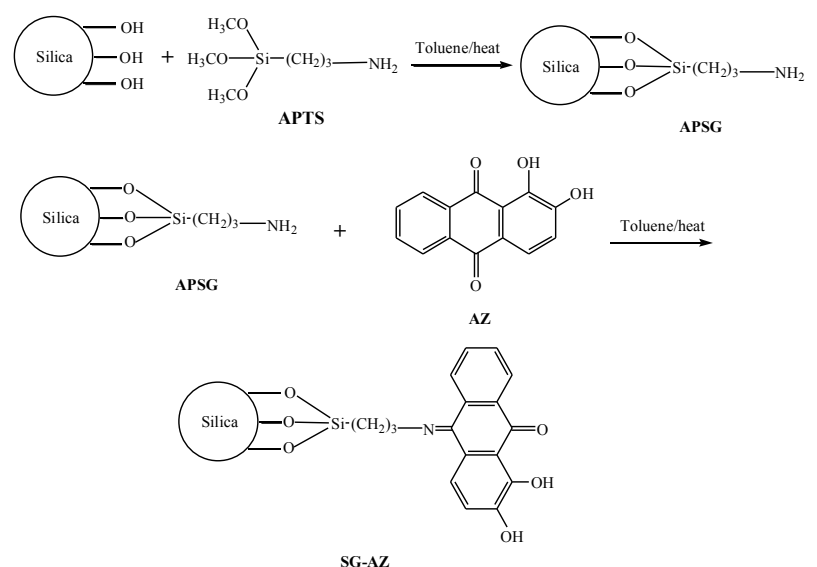

Scheme 1 Synthetic route of the SG-AZ. 


\section{General procedure for adsorption-determination of metal Ions (analytes)}

Data are given as the mean of three replicates. The applications were repeated five times for statistical evaluation. A total of $30 \mathrm{mg}$ of SG-AZ sorbent was suspended with constant stirring for $10 \mathrm{~min}$ in $10 \mathrm{~mL}$ of $1.0 \mu \mathrm{g} / \mathrm{mL} \mathrm{Cd}(\mathrm{II}), \mathrm{Cu}(\mathrm{II}), \mathrm{Ni}(\mathrm{II}), \mathrm{Pb}$ (II) and $\mathrm{Zn}$ (II) at the desired $\mathrm{pH}$. The mixture was shaken vigorously for $30 \mathrm{~min}$ to facilitate extraction. The modified silica gel was filtered and, washed with DDW. The concentrations of the metal ions in solution were directly determined by ICP-OES. Then the sorbent was shaken with $10-25 \mathrm{~mL}$ of $1.5 \mathrm{~mol} / \mathrm{L} \mathrm{HNO}_{3}$ for $30 \mathrm{~min}$ and filtered again. The desorbed metal ions in the solution were measured by ICP-OES.

\section{Results and Discussion}

\section{Characterization}

The formation of the modified silica gel was confirmed using FTIR analysis. The peaks of APSG at $469,802,1099,1628.02$ and $2926 \mathrm{~cm}^{-1}$ are be attributed to $\delta(\mathrm{Si}-\mathrm{O}-\mathrm{Si}), v(\mathrm{Si}-\mathrm{O}-$ $\mathrm{Si})$, longitudinal $\mathrm{SiO}_{2}$ lattice vibration, $\delta\left(\mathrm{H}_{2} \mathrm{O}\right)$, and $v\left(\mathrm{CH}_{3}\right)$, respectively. The peaks at 3431 and $1560 \mathrm{~cm}^{-1}$ were assigned to $v\left(\mathrm{NH}_{2}\right)$ and $\delta\left(\mathrm{NH}_{2}\right)$, respectively ${ }^{37}$.

Compared to APSG, the FT-IR of SG-AZ showed remarkable spectral changes, notably in the range of $1000-1600 \mathrm{~cm}^{-1}$. A new peak appeared at $1632 \mathrm{~cm}^{-1}$ and was attributed to the stretching vibration of both $\mathrm{C}=\mathrm{O}$ and $\mathrm{C}=\mathrm{N}$. The phenyl vibrations appeared at 1586.83 , 1452.04 and $1330.48 \mathrm{~cm}^{-1}$. The FTIR spectrum also showed the presence of unreacted $\mathrm{OH}$ groups of $\mathrm{AZ}$ at $3357.96 \mathrm{~cm}^{-1}$ and the $\mathrm{Si}-\mathrm{O}$ of the silica gel as a strong broad band at 1048 $\mathrm{cm}^{-1}$. These observations support the immobilization of $\mathrm{AZ}$ on the silica surface through an $\mathrm{O}_{3} \mathrm{Si}-\left(\mathrm{CH}_{2}\right)_{3}-$ spacer.

Carbon, hydrogen and nitrogen elemental analyses were consistent with the increasing amount of silylating agent on the surface (Table 1). These values confirm that the APSG reaction with activated silica gel and $\mathrm{AZ}$ molecules being covalently bonded to the surface. ${ }^{38}$

Table 1. Percentages (\%) of carbon $(\mathrm{C})$, hydrogen $(\mathrm{H})$ and nitrogen $(\mathrm{N})$ for the matrices $\mathrm{SiO}_{2}$, APSG, and SG-AZ.

\begin{tabular}{cccc}
\hline Surface & Carbon, $\%$ & Nitrogen, $\%$ & Hydrogen, $\%$ \\
\hline $\mathrm{SiO}_{2}$ & 0.00 & 0.00 & 0.00 \\
$\mathrm{APSG}$ & 4.73 & 1.36 & 2.99 \\
$\mathrm{SG}-\mathrm{AZ}$ & 28.6 & 0.73 & 1.96 \\
\hline
\end{tabular}

\section{Effect of $\mathrm{pH}$}

The acidity of a solution has two effects on metal adsorption. First, protons in an acidic solution can protonate the binding sites of the chelating molecules. Secondly, the hydroxide in a basic solution may complex and precipitate many metals. Therefore, the $\mathrm{pH}$ of a solution is the first parameter to be optimized. The reactions between $\mathrm{Cd}(\mathrm{II}), \mathrm{Cu}(\mathrm{II}), \mathrm{Ni}(\mathrm{II})$, $\mathrm{Pb}(\mathrm{II})$, and $\mathrm{Zn}(\mathrm{II})$ and the adsorbent (SG-AZ) can be influenced by changes in the $\mathrm{pH}$ value. In order to optimize this parameter, the effect of the $\mathrm{pH}$ on metal ion sorption onto SG-AZ was investigated by equilibrating $30 \mathrm{mg} \mathrm{SG}-\mathrm{AZ}$ with $10 \mathrm{~mL}$ of buffer solutions containing $1.0 \mu \mathrm{g} / \mathrm{mL}$ of metal ions at different $\mathrm{pH}(1-8)$. 
The adsorption quantity of metal ions increases with the increases of $\mathrm{pH}$ (Figure 1). Quantitative extraction ( $>98 \%$ ) of the analytes occurs in the $\mathrm{pH}$ range of 4-6. In order to avoid hydrolyzing at higher $\mathrm{pH}$ values, a $\mathrm{pH}$ of 5 was chosen as the optimum $\mathrm{pH}$ for further studies.

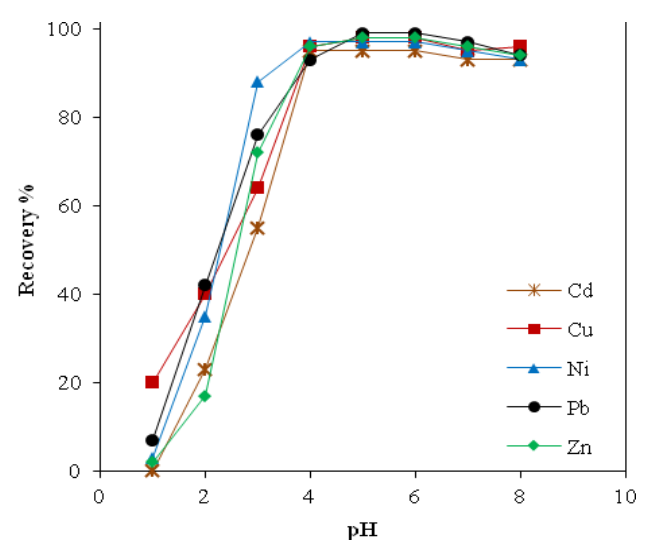

Figure 1. Effect of $\mathrm{pH}$ on metal ions adsorption. Other conditions: $30 \mathrm{mg}$ of the sorbent, shaking time $30 \mathrm{~min}$, temperature $25^{\circ} \mathrm{C}$, sample volume $10 \mathrm{~mL}$.

\section{Effect of the shaking time}

Shaking time is another important factor in evaluating the affinity of SG-AZ to Cd(II), $\mathrm{Cu}(\mathrm{II}), \mathrm{Ni}(\mathrm{II}), \mathrm{Pb}(\mathrm{II})$, and $\mathrm{Zn}(\mathrm{II})$. Shaking times (ranging from 2 to $60 \mathrm{~min}$ ) were studied for the percentage extraction of the five ions following the recommended procedure. Figure 2 shows the effect of shaking time on the extraction of each metal ion at the optimum $\mathrm{pH}$. The percentage extractions of $\mathrm{Cd}(\mathrm{II}), \mathrm{Cu}(\mathrm{II}), \mathrm{Ni}(\mathrm{II}), \mathrm{Pb}(\mathrm{II})$ and $\mathrm{Zn}$ (II) reach maximum adsorption $(>95 \%$ ) within $15 \mathrm{~min}$. These results indicate that SG-AZ has rapid adsorption kinetics. Hence, 30 min of shaking is sufficient to reach the maximum simultaneous separation of all the studied metals.

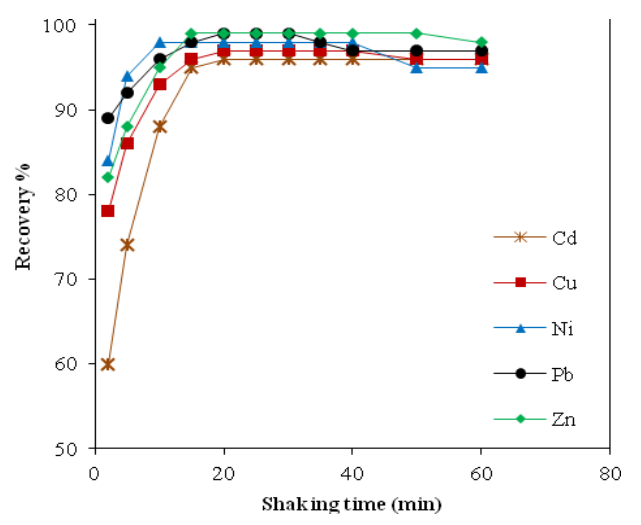

Figure 2. Effect of shaking time on metal ions adsorption.

Other conditions: $30 \mathrm{mg}$ of the sorbent, $\mathrm{pH} 5.0$, temperature $25^{\circ} \mathrm{C}$, sample volume $10 \mathrm{~mL}$. 


\section{Effect of the sorbent amount}

To study the effect of SG-AZ amount on quantitative retention of the analytes, different amounts of SG-AZ from 10 to $100 \mathrm{mg}$ were added to the solution following the recommended procedure. The most suitable mass of SG-AZ sorbent for good extraction was $30 \mathrm{mg}$ for the metal ions under investigation (Figure 3).

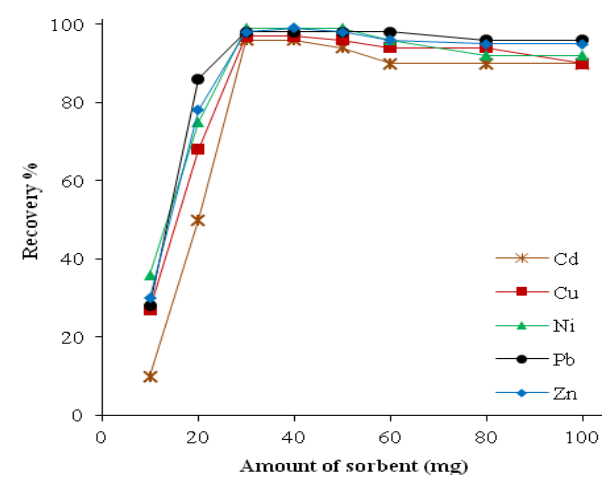

Figure 3. Effect of amount of sorbent on metal ions adsorption.

Other conditions: $\mathrm{pH} 5.0$, temperature $25^{\circ} \mathrm{C}$, shaking time $30 \mathrm{~min}$, sample volume $10 \mathrm{~mL}$.

\section{Adsorption capacity}

The capacity of the adsorbent is an important factor because it determines how much adsorbent is required to quantitatively remove a specific amount of metal ions from a solution. ${ }^{39}$ The adsorption capacity for each metal ion was determined by shaking $30 \mathrm{mg}$ of SG-AZ with $50 \mathrm{~mL}$ of various concentrations of $\mathrm{Cd}(\mathrm{II}), \mathrm{Cu}(\mathrm{II}), \mathrm{Ni}(\mathrm{II}), \mathrm{Pb}(\mathrm{II})$, and $\mathrm{Zn}$ (II) for $1 \mathrm{~h}$ at optimum conditions. The adsorption capacity was calculated using the following equation:

$$
q=\frac{\left(C_{o}-C\right) V}{W}
$$

where $\mathrm{q}$ is the amount of metal ion sorbed onto a unit amount of the adsorbent ( $\mu \mathrm{mol} / \mathrm{g}), \mathrm{C}_{\mathrm{o}}$ and $\mathrm{C}$ are the concentrations of metal ions in the initial and equilibrium concentrations in aqueous phase $(\mu \mathrm{mol} / \mathrm{L}), \mathrm{V}$ is the volume of the aqueous phase $(\mathrm{L})$, and $\mathrm{W}$ is the dry weight of the sorbent $(\mathrm{g})^{12,19,40}$.

The adsorption capacity of the various metal ions differs due to their size, degree of hydration and the value of their binding constant with the adsorbent. The maximum adsorption capacity was $67.4,163.5,212.8,76.4$ and $180.3 \mu \mathrm{mol} / \mathrm{g}$ for $\mathrm{Cd}(\mathrm{II}), \mathrm{Cu}(\mathrm{II}), \mathrm{Ni}(\mathrm{II})$, $\mathrm{Pb}(\mathrm{II})$ and $\mathrm{Zn}(\mathrm{II})$, respectively.

\section{Effect of foreign ions}

The effect of different cations and anions on the adsorption of the five metal ions analytes was investigated. In these studies, $1.0 \mu \mathrm{g} / \mathrm{mL}$ each of $\mathrm{Cd}(\mathrm{II}), \mathrm{Cu}(\mathrm{II}), \mathrm{Ni}(\mathrm{II}), \mathrm{Pb}$ (II) and $\mathrm{Zn}$ (II) solutions containing the interfering ions were analyzed according to the general procedure. The tolerance limit was set at the amount of ions that reduced the recovery of the examined elements to less than $95 \%$. 
As shown in Table 2, 500-2000 fold of common electrolytes did not significantly interfere in the preconcentration and determination of the analytes, indicating that the new sorbent is suitable for adsorption of $\mathrm{Cd}(\mathrm{II}), \mathrm{Cu}(\mathrm{II}), \mathrm{Ni}(\mathrm{II}), \mathrm{Pb}(\mathrm{II})$ and $\mathrm{Zn}(\mathrm{II})$ in high concentration of electrolytes.

Table 2. Effect of foreign ions on percent recovery of $1.0 \mu \mathrm{g} / \mathrm{mL}$ metal ions.

\begin{tabular}{ccccccc}
\hline \multirow{2}{*}{ Foreign ion } & $\begin{array}{c}\text { Concentration, } \\
\mu \mathrm{g} / \mathrm{mL}\end{array}$ & $\mathrm{Cd}$ & $\mathrm{Cu}$ & $\mathrm{Ni}$ & $\mathrm{Pb}$ & $\mathrm{Zn}$ \\
\cline { 3 - 7 } & 500 & 95.3 & 98.4 & 99.4 & 99.8 & 99.1 \\
$\mathrm{Ca}^{2+}$ & 500 & 96.2 & 96.8 & 99.3 & 99.7 & 99.3 \\
$\mathrm{Mg}^{2+}$ & 500 & 96.0 & 98.6 & 99.6 & 99.5 & 99.5 \\
$\mathrm{Ba}^{2+}$ & 2000 & 96.8 & 98.2 & 99.8 & 99.8 & 95.6 \\
$\mathrm{NH}_{4} \mathrm{Cl}$ & 2000 & 95.6 & 97.7 & 99.2 & 97.2 & 96.8 \\
$\mathrm{KNO}_{3}$ & 2000 & 95.4 & 97.4 & 98.3 & 98.3 & 95.4 \\
$\mathrm{Na}_{3} \mathrm{PO}_{4}$ & 2000 & 96.9 & 96.8 & 98.1 & 95.7 & 98.7 \\
$\mathrm{NaCl}$ & & & & &
\end{tabular}

\section{Accuracy and precision of the method}

To check the accuracy of our method, Standard Reference Material (SRM) 1643c from the National Institute of Standard and Technology (NIST, Gaithersburg, MD) was used. Our results agreed with the NIST certified levels as shown in Table 3.

Table 3. Analysis of standard reference material (NIST 1643c, water) ${ }^{a}$.

\begin{tabular}{ccc}
\hline Metal ion & Found, $\mu \mathrm{g} / \mathrm{L}$ & Certified, $\mu \mathrm{g} / \mathrm{L}$ \\
\hline $\mathrm{Cd}$ & $11.4 \pm 1.7^{b}$ & $12.2 \pm 1.0$ \\
$\mathrm{Cu}$ & $23.8 \pm 3.2$ & $22.3 \pm 2.8$ \\
$\mathrm{Ni}$ & $62.3 \pm 5.9$ & $60.6 \pm 7.3$ \\
$\mathrm{Zn}$ & $74.6 \pm 2.5$ & $73.9 \pm 0.9$ \\
\hline
\end{tabular}

${ }^{a} \mathrm{~Pb}$ was not included in the NIST reference standard. ${ }^{b} \bar{X} \pm s(n=5), \bar{X}$ : average value for five determinations and S: standard deviation.

The relative standard deviation (RSD) for the five replicate determinations was $\leq 3 \%$, indicating that the method is precise for the analysis of trace $\mathrm{Cd}(\mathrm{II}), \mathrm{Cu}(\mathrm{II}), \mathrm{Ni}(\mathrm{II}), \mathrm{Pb}$ (II) and $\mathrm{Zn}(\mathrm{II})$ in $50 \mathrm{~mL}$ solution samples. The limit of detection (LOD) and the limit of quantification (LOQ) for the five metals were determined by analyzing five portions of standard solutions simultaneously following the general procedure. The LOD values [defined as $(3 \sigma)$ where $\sigma$ is the standard deviation] were $0.64,0.47,0.98,0.83$ and $0.75 \mu \mathrm{g} / \mathrm{L}$ for $\mathrm{Cd}(\mathrm{II}), \mathrm{Cu}(\mathrm{II}), \mathrm{Ni}(\mathrm{II})$, $\mathrm{Pb}(\mathrm{II})$ and $\mathrm{Zn}(\mathrm{II})$, respectively. The LOQ values $(10 \sigma)$ were $2.10,1.52,3.27,2.77$ and $2.50 \mu \mathrm{g} / \mathrm{L}$ for $\mathrm{Cd}(\mathrm{II}), \mathrm{Cu}(\mathrm{II}), \mathrm{Ni}(\mathrm{II}), \mathrm{Pb}(\mathrm{II})$ and $\mathrm{Zn}(\mathrm{II})$, respectively.

\section{Application of the method}

The proposed method was applied to the determination of $\mathrm{Cd}(\mathrm{II}), \mathrm{Cu}(\mathrm{II}), \mathrm{Ni}(\mathrm{II}), \mathrm{Pb}$ (II) and $\mathrm{Zn}$ (II) in tap water samples by ICP-AES. The standard addition method was used for the analysis of the water samples and the results for the recovery of both metals are presented in Table 4. As shown in Table 4, the recoveries of analytes were in the range of 96.13-98.90\%, 
with RSD less than $3 \%$. Therefore, SG-AZ is suitable for the preconcentration of Cd(II), $\mathrm{Cu}(\mathrm{II}), \mathrm{Ni}(\mathrm{II}), \mathrm{Pb}$ (II) and $\mathrm{Zn}$ (II) from water samples prior to ICP-OES analysis.

Table 4. Analytical results for the determination of metal ions in tap water samples.

\begin{tabular}{ccccc}
\hline Metal ion & Added $\mu \mathrm{g} / \mathrm{L}$ & Found, $\mu \mathrm{g} / \mathrm{L}$ & Recovery, \% & RSD, \% \\
\hline $\mathrm{Cd}$ & 0.0 & $\mathrm{ND}^{a}$ & - & - \\
& 5.0 & $4.83 \pm 0.06^{b}$ & 96.60 & 1.15 \\
& 10.0 & $9.80 \pm 0.07$ & 97.97 & 0.58 \\
$\mathrm{Cu}$ & 0.0 & $4.40 \pm 0.33$ & - & - \\
& 5.0 & $9.27 \pm 0.28$ & 96.87 & 3.03 \\
& 10.0 & $14.29 \pm 0.31$ & 98.90 & 2.17 \\
$\mathrm{Ni}$ & 0.0 & $5.66 \pm 0.13$ & - & - \\
& 5.0 & $10.49 \pm 0.04$ & 96.53 & 0.36 \\
$\mathrm{~Pb}$ & 10.0 & $15.43 \pm 0.15$ & 97.67 & 0.97 \\
& 0.0 & $2.19 \pm 0.15$ & - & - \\
$\mathrm{Zn}$ & 5.0 & $7.00 \pm 0.16$ & 96.13 & 2.23 \\
& 10.0 & $11.92 \pm 0.22$ & 97.23 & 1.89 \\
& 0.0 & $41.92 \pm 0.14$ & - & - \\
& 5.0 & $46.76 \pm 0.17$ & 96.87 & 0.36 \\
& 10.0 & $51.74 \pm 0.23$ & 98.20 & 0.44 \\
\hline
\end{tabular}

${ }^{a} N D$ : not detective. ${ }^{b} \bar{X} \pm s \quad(n=5), \bar{X}$ : average value for five determinations and $S:$ standard deviation.

\section{Comparison with other preconcentrating matrices}

The sorption capacity of SG-AZ compared with other matrices is shown in Table 5 . The new matrix in this study shows better or comparable capacity to most other matrices used for the enrichment of $\mathrm{Cd}(\mathrm{II}), \mathrm{Cu}(\mathrm{II}), \mathrm{Ni}(\mathrm{II}), \mathrm{Pb}(\mathrm{II})$ and $\mathrm{Zn}(\mathrm{II})$. However, SG-AZ exhibits a lower capacity than silica gel modified with 2-aminomethylpyridine. ${ }^{22}$ In general SG-AZ offer good sorption capacity values. The total shaking time required for quantitative extraction by the present matrix is on the same order reported for other matrices. Matrix effects with the present collectors are low, as shown by natural water sample analysis (Table 4).

Table 5. Comparison of sorption capacities $(\mu \mathrm{mol} / \mathrm{g})$.

\begin{tabular}{|c|c|c|c|c|c|c|}
\hline \multirow{2}{*}{ Sorbent } & \multicolumn{5}{|c|}{ Metal ion } & \multirow[b]{2}{*}{ Ref. } \\
\hline & $\mathrm{Cd}$ & $\mathrm{Cu}$ & $\mathrm{Ni}$ & $\mathrm{Pb}$ & $\mathrm{Zn}$ & \\
\hline 4-Amino-2-mercaptopyrimidine & - & 450 & - & - & - & [13] \\
\hline benzophenone 4-aminobezoyl-hydrazone & - & 0.008 & 0.009 & - & 0.008 & [19] \\
\hline 1,8-Dihydroxyanthraquinone & 70.2 & - & - & 76.0 & 180 & [21] \\
\hline 2-Aminomethylpyridine & - & 840 & 400 & - & 220 & {$[22]$} \\
\hline p-Dimethylaminobenzaldehyde & - & 0. & 1.15 & 0.45 & 0.56 & {$[23]$} \\
\hline Ethyl-2-benzothiazolylacetate & 7 & 140 & 5 & 220 & - & [26] \\
\hline 5-Benzylidene-2-thiobarbituric & 110 & 150 & 20.0 & 60.0 & 30.0 & [41] \\
\hline 1,2-Dihydroxyanthraquinone & 67.4 & 164 & 213 & 76.4 & 180 & $\begin{array}{c}\text { Present } \\
\text { work }\end{array}$ \\
\hline
\end{tabular}

\section{Conclusion}

Silica gel modified with 1,2-dihydroxyanthraquinone is a new solid-phase extractant for the preconcentration of trace $\mathrm{Cd}(\mathrm{II}), \mathrm{Cu}(\mathrm{II}), \mathrm{Ni}(\mathrm{II}), \mathrm{Pb}(\mathrm{II})$ and $\mathrm{Zn}$ (II) from sample solutions. The short loading time of this sorbent makes the analytical procedure reasonably fast. The order of sorption capacities order was $\mathrm{Ni}>\mathrm{Zn}>\mathrm{Cu}>\mathrm{Pb}>\mathrm{Cd}$. This newly developed 
method was successfully applied to the analysis of trace metal ions in natural water samples. The precision and accuracy of the method are satisfactory. The new modified silica gel may be used as an inexpensive, effective, and alternative sorbent for the removal of five metal ions from aqueous solutions.

\section{Acknowledgment}

This project was funded by the Deanship of Scientific Research (DSR), King Abdulaziz University, Jeddah, under grant no. (18-H 013/429). The author, therefore, acknowledge with thanks DSR technical and Financial support.

\section{References}

1. Zhao LY L, Schulin R, and Nowack B. Environ. Pollut. 2009, 157, 823.

2. Maanan M Environ. Pollut. 2008, 153, 176.

3. Manahan S E, Environmental Science and Technology; CRC Press, Boca Raton, USA, 2000.

4. Pyrzynska K and Trojanowicz M Crit. Rev. Anal. Chem. 1999, 29, 313.

5. He Q, Chang X, Wu Q, Huang X, Hu Z and Zhai Y Anal. Chim. Acta 2007, 605, 192.

6. Sales J A A, Faria F P, Prado A G S and Airoldi C Polyhedron 2004, 23, 719.

7. Vansant, E. F. ; Van der Voort, P.; Vrancken, K. C. Stud. Surf. Sci. Catal. 1995, 93, 149.

8. Zaporozhets O, Petruniock N, Bessarabova O and Sukhan V Talanta 1999, 49, 899.

9. Prado A G S and Airoldi C Anal. Chim. Acta 2001, 432, 201.

10. Kim J S and Yi J Sep. Sci. Technol. 1999, 34, 2957.

11. Camel V Spectrochim. Acta Part B 2003, 58, 1177.

12. Zhang L, Chang X, Zhai Y, He Q, Huang X, Hu Z and Jiang N Anal. Chim. Acta 2008, 629, 84 .

13. Pereira A S, Ferreira G, Caetano L, Martines M A U, Padilha P M, Santos A and Castro G R J. Hazard. Mater. 2010, 175, 399.

14. Alcantara I L, Roldan P S, Castro G R, Moraes F V, Silva F A, Padilha C C F, Oliveira J D and Padilha P M Anal. Sci. 2004, 20, 1029.

15. Hatay I, Gup R and Ersoz M J. Hazard. Mater. 2008, 150, 546.

16. Gao B, An F and Liu K Appl. Surf. Sci. 2006, 253, 1946.

17. Castro G R, Cristante V M, Padilha C C F, Jorge S M A, Florentino A O, Prado A G S and Padilha P M Microchim. Acta 2008, 160, 203.

18. Cestari A R, Viera E F S, Nascimento A J P, de Oliveira F J R, Bruns R E and Airoldi C J. Colloid Interface Sci. 2001, 241, 45.

19. Gubbuk I H, Gup R and Ersoz M J. Colloid Interface Sci. 2008, 320, 376.

20. Zhang Y, Qu R, Sun C, Chen H, Wang C, Ji C, Yin P, Sun Y, Zhang H and Niu Y J. Hazard. Mater. 2009, 163, 127.

21. Goswami A and Singh A K Talanta 2002, 58, 669.

22. Sales J A, Faria F P, Prado A G and Airoldi C Polyhedron 2004, 23, 719.

23. Cui Y, Chang X, Zhu X, Luo H, Hu Z, Zou X and He Q Microchemical J. 2007, 87, 20.

24. Chang X, Luo H, Cui Y, Zhu X, Zhai Y, Hu and He Q J. Mol. Struct. 2008, 891, 45.

25. Madrakian T, Zolfigol M A and Solgi M J. Hazard. Mater. 2008, 160, 468.

26. Aeungmaitrepirom W, Ngeontae W and Tuntulani T Anal. Scien. 2009, 25, 1477.

27. Padilha P M, Gomes L A M, Padilha C C F, Moreira J C and Dias Filho N L Anal. Lett. 1999, 32, 1807.

28. Espinola J G P, Oliveira, S F, Lemus W E S, Souza A G, Airoldi C and Moreira J C A Colloids Surf. A Physicochem. Eng. Aspects 2000, 166, 45.

29. Goswami A and Singh A K Anal. Chim. Acta 2002, 454, 229. 
30. Kallury K M R, Lee W E and Thompson M Anal. Chem. 1993, 65, 2459.

31. Fujiwara S T, Pessoa C A and Gushikem Y Anal. Lett. 2002, 35, 1117.

32. Fisher H E, King S A, Miller J B, Ying J Y, Benzinger J B and Schwartz J Inorg. Chem. 1991, 30, 4403.

33. Guo Y, Hu C, Jiang C, Yang Y, Jiang S, Li X and Wang E J. Catal. 2003, 217, 141.

34. Valkenberg M H and Holderich W F Catal. Rev. 2002, 44, 321.

35. Prado A G S and Airoldi C Fresenius J. Anal. Chem. 2001, 371, 1028.

36. Clark J H and Macquiarrie D J Chem. Commun. 1998, 853.

37. Abou-El-Sherbini K, Kenawy I, Hamed M, Issa R and Elmorsi R Talanta 2002, 58, 289.

38. Prado A G S and Airoldi C J. Colloid Interface Sci. 2001, 236, 161.

39. Dev K and Rao G N Talanta 1995, 42, 591.

40. Gubbuk I H, Gup R, Kara H and Ersoz M Desalination 2009, 249, 1243.

41. Mahmoud M E, Haggag S S and Hegazi A H J. Colloid Interface Sci. 2006, 300, 94. 


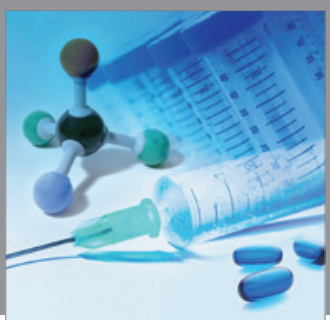

International Journal of

Medicinal Chemistry

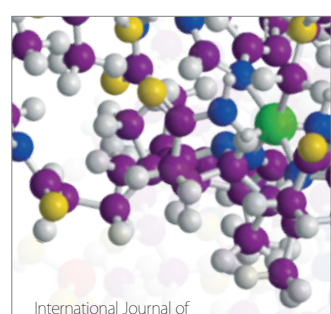

Carbohydrate Chemistry

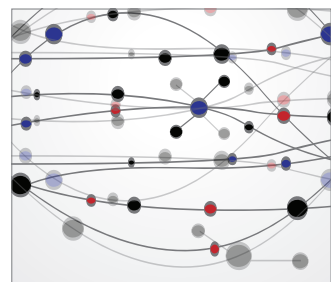

The Scientific World Journal
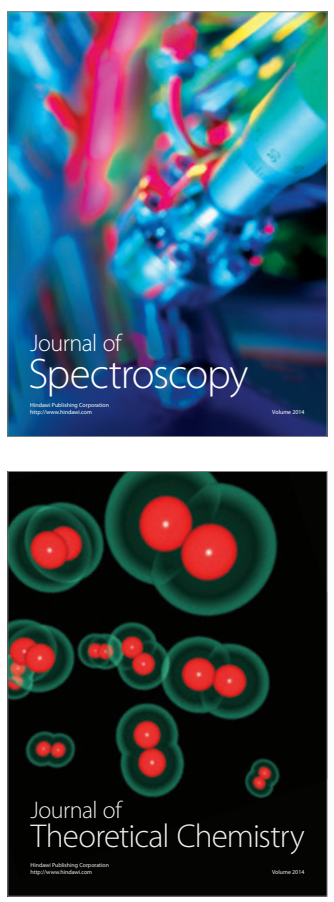
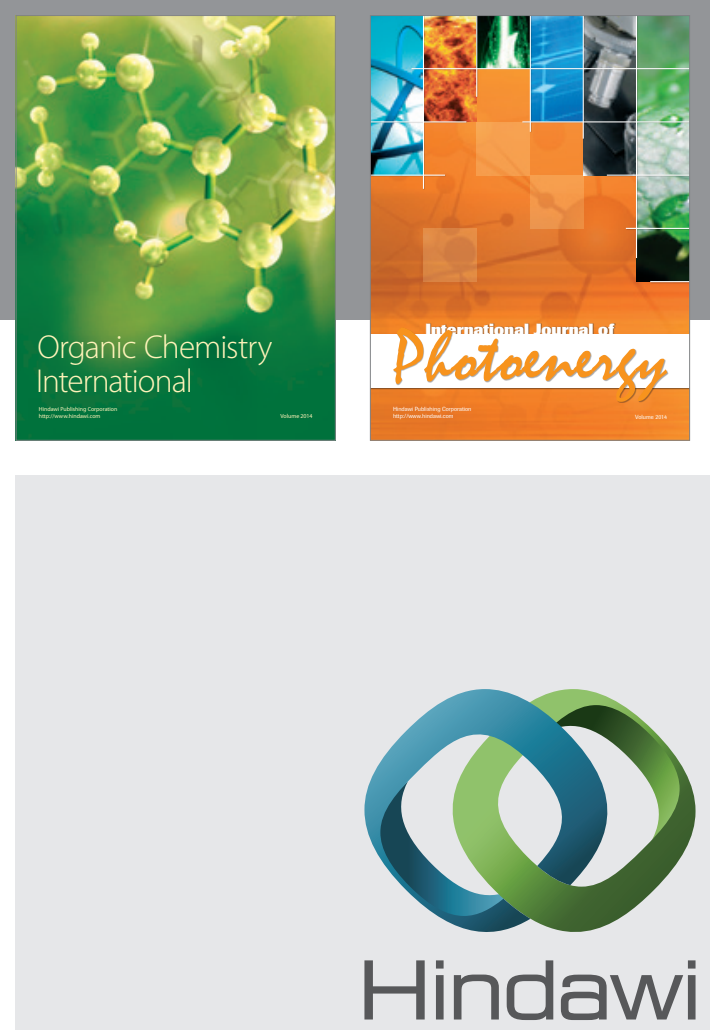

Submit your manuscripts at

http://www.hindawi.com
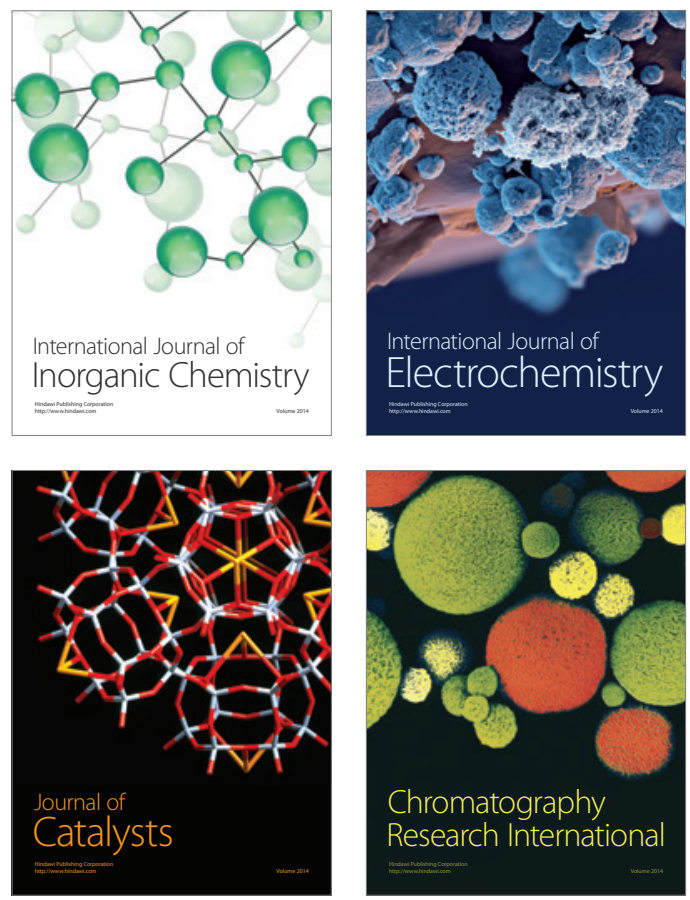
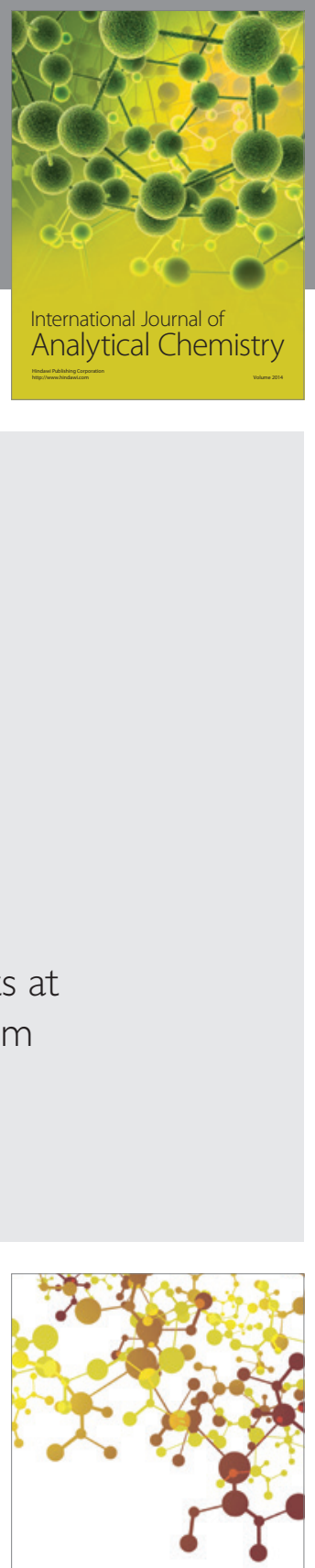

Journal of

Applied Chemistry
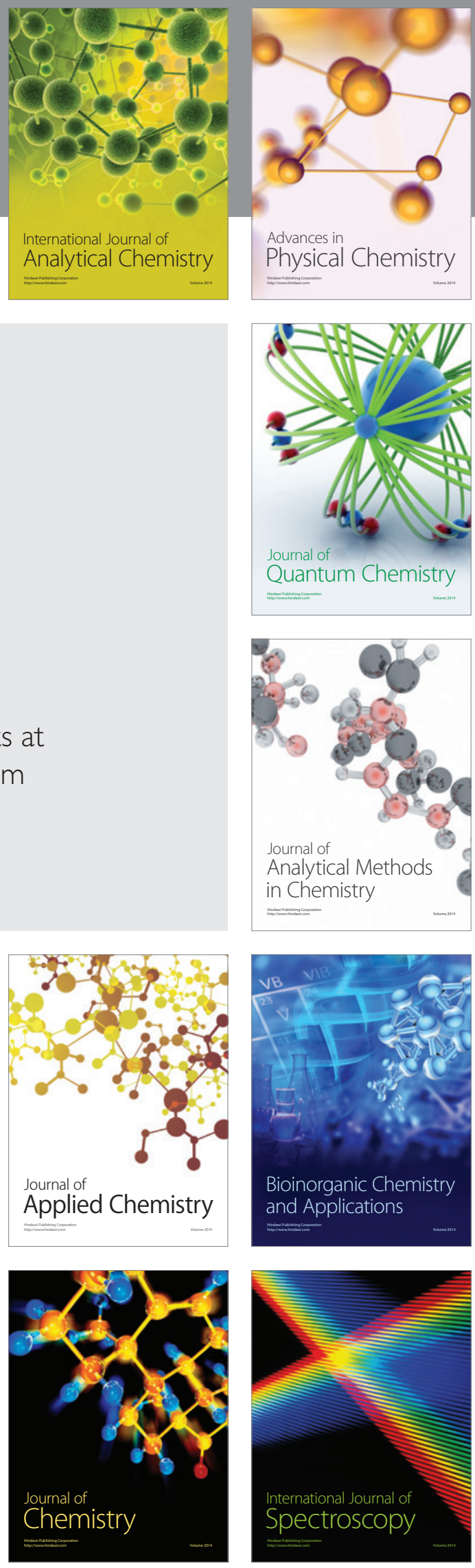